\title{
Gambaran status karies gigi pada mahasiswa asal Kabupaten Mimika yang mempunyai kebiasaan menyirih di Manado
}

\author{
${ }^{1}$ Sarlota Uamang \\ ${ }^{2}$ Michael A. Leman \\ ${ }^{2}$ Shane H. R. Ticoalu \\ ${ }^{1}$ Kandidat Skripsi Program Studi Pendidikan Dokter Gigi Fakultas Kedokteran \\ ${ }^{2}$ Program Studi Pendidikan Dokter Gigi Fakultas Kedokteran \\ ${ }^{3}$ Bagian Anatomi-Histologi Fakultas Kedokteran \\ Universitas Sam Ratulangi Maando \\ Email: sarlotauamang@gmail.com
}

\begin{abstract}
Caries is one of the dentine diseases which causes tooth cavity. In people with chewing betel habit, caries occurs due to less of oral hygiene. Chewing betel habit is inherited from generation to generation to prevent tooth decay, albeit, this habit can cause caries as an impact of chewing betel inappropriately including the frequency, duration, and number of betles consumed. This study was aimed to obtain the caries status of students from Mimika who had chewing betel habit in Manado. This was a descriptive study with a cross-sectional design. Subjects were 45 students from Mimika that had chewing betel habit obtained by using total sampling method. The results showed that the average of DMF-T index of subjects was 5,9 (D/Decay 222, M/Missing 30, F/Filling 15). The majority of subjects had that habit for $>5$ years, 1-5 times of chewing per day, and less than 5 betels consumed per day. Conclusion: Status of caries in students of Mimika who had chewing betel habit in Manado was classified in high category.
\end{abstract}

Keywords: caries status, chewing betel habit

\begin{abstract}
Abstrak: Karies gigi merupakan suatu penyakit jaringan keras gigi yang menyebabkan kavitas pada gigi. Karies gigi pada penyirih terjadi karena kurangnya pemeliharaan kebersihan gigi dan mulut. Kebiasaan menyirih merupakan kebiasaan masyarakat peramu yang diturunkan dari generasi ke generasi untuk merawat gigi namun dapat menyebabkan karies gigi pada penyirih akibat pola menyirih yang tidak teratur seperti frekuensi menyirih, lamanya menyirih dan jumlah pinang yang dikonsumsi. Penelitian ini bertujuan untuk mengetahui gambaran status karies gigi pada mahasiswa asal Kabupaten Mimika yang mempunyai kebiasaan menyirih di Manado. Jenis penelitian ialah deskriptif dengan desain potong lintang. Subyek penelitian berjumlah 45 mahasiswa dengan kebiasaan menyirih berasal dari Kabupaten Mimika, diperoleh dengan metode total sampling. Hasil penelitian menunjukkan rerata indeks DMF-T pada subyek penelitian yaitu 5,9 dengan nilai D (Decay) 222, M (Missing)30, F (Filling) 15. Mayoritas subyek peneltian telah menyirih $>5$ tahun, frekuensi menyirih 1-5 kali sehari, dan jumlah pinang yang dikonsumsi sehari $<5$ buah. Simpulan: Status karies pada mahasiswa asal Kabupaten Mimika yang mempunyai kebiasaan menyirih di Manado tergolong kategori tinggi.
\end{abstract}

Kata kunci: status karies, kebiasaan menyirih

Karies gigi merupakan penyakit jaringan keras gigi yaitu email, dentin, dan sementum yang disebabkan oleh aktivitas jasad renik yang ada dalam suatu karbohidrat yang difermentasikan. Penyakit karies gigi ini dapat dialami oleh semua 
tingkatan usia sehingga merupakan masalah utama dalam masyarakat dan perlu mendapat perhatian serius karena prevalensinya sangat cepat meningkat di banyak negara. ${ }^{1,2}$

Berdasarkan Riset Kesehatan Dasar (RISKEDAS) tahun 2013, prevalensi indeks DMF-T (decayed, missing, fillingteeth) di Indonesia sebesar 4,6 yang berarti kerusakan gigi penduduk Indonesia 460 gigi per 100 orang dan termasuk dalam kategori tinggi. Indeks DMF-T pada lakilaki sebesar 4,1 (kategori sedang) dan pada perempuan sebesar 4,9 (kategori tinggi). ${ }^{3}$

Kebiasaan menyirih atau yang lebih dikenal dengan "mengunyah pinang" di Papua merupakan kebiasaan masyarakat peramu yang diturunkan dari generasi ke generasi dan telah menjadi bagian yang tidak dapat dipisahkan dalam kehidupan masyarakat Papua. Penelitian yang dilakukan oleh Dawn pada tahun 1995 di Papua Nugini dan Jawa Timur menunjukkan bahwa karies gigi frekuensinya tidak banyak mencolok di antara para pengunyah sirih pinang karena kebiasaan ini juga berfungsi sebagai salah satu cara untuk merawat gigi. Daun sirih (Piper Betle Linn.) mengandung minyak atsiri yang berfungsi sebagai zat anti bakteri. Daun sirih ini juga digunakan sebagai antimikroba terhadap Streptococcus mutans yang merupakan bakteri yang paling sering mengakibatkan kerusakan pada gigi. ${ }^{4}$

Pada pengunyah sirih pinang yang tidak membersihkan gigi dalam periode jangka panjang tertentu maka gigi mereka akan berubah warna menjadi hitam dan tidak memberikan rasa nyeri pada gigi yang berlubang sehingga akan memperburuk kondisi gigi. Selain itu, pengunyah sirih pinang yang mengonsumsi pinang terus menerus juga dapat menyebabkan rasa tidak nyaman pada mukosa mulut. ${ }^{5}$

Terdapat cukup banyak mahasiswa asal Kabupaten Mimika yang berdomisili di Manado dan kuliah di beberapa universitas negeri maupun swasta di Sulawesi Utara. Kegiatan menyirih yang dilakukan seharihari oleh mahasiswa asal Kabupaten Mimika ini sama dengan kegiatan menyirih yang biasanya dilakukan oleh masyarakat yang berada di Kabupaten Mimika. Penelitian ini bertujuan untuk mengetahui gambaran status karies gigi pada mahasiswa asal kabupaten Mimika yang mempunyai kebiasaan menyirih di Manado.

\section{METODE PENELITIAN}

Jenis penelitian yang digunakan ialah deskriptif dengan desain potong lintang. Penelitian ini dilakukan di asrama mahasiswa Kabupaten Mimika yang bertempat di Jln. Batu Kota Bawah Lingkungan I Kecamatan Malalayang Manado pada bulan Maret 2016. Populasi dalam penelitian ini merupakan mahasiswa asal Kabupaten Mimika yang berada di asrama tersebut dengan kebiasaan menyirih sebanyak 45 orang. Karena jumlah populasi yang kurang dari 100, maka seluruh populasi dijadikan subyek penelitian (tital sampling). Kriteria inklusi ialah mahasiswa yang mempunyai kebiasaan menyirih, bersedia dijadikan subjek penelitian, dan berada di tempat sewaktu penelitian dilaksanakan.

Variabel penelitian yang diteliti ialah status karies gigi yang diukur dengan indeks DMF-T. Kriteria perhitungan DMFT menurut WHO sebagai berikut: ${ }^{6}$
a. Sangat rendah : $0,0-1,1$
b. Rendah : : $1,2-2,6$
c. Sedang : $2,7-4,4$
d. Tinggi : $4,5-6,5$
e. Sangat tinggi : $>6,6$

Pengolahan data dilakukan dengan menggunakan Microsoft Office Excel dan disajikan dalam bentuk tabel. Data tersebut kemudian diolah dengan cara perhitungan persentase.

\section{HASIL PENELITIAN}

Penelitian ini dilakukan terhadap 45 orang mahasiswa dengan kebiasaan menyirih di asrama mahasiswa Kabupaten Mimika yang berada di Jln. Batu Kota Bawah Lingk I, Kecamatan Malalayang Manado. Karakteristik responden penelitian dilihat berdasarkan jenis kelamin dan usia. Mahasiswa yang tinggal di asrama berusia 
16-30 tahun, dan yang berjenis kelamin perempuan lebih banyak dibandingkan laki-laki. Kelompok usia 21-25 tahun yang terbanyak dibandingkan dengan kelompok usia lainnya (Tabel 1).

Hasil pemeriksaan status karies pada responden penelitian mendapatkan rerata indeks DMF-T 5,9 yang tergolong dalam kategori tinggi (Tabel 2).

Berdasarkan hasil pemeriksaan, rerata indeks DMF-T responden perempuan lebih tinggi dibandingkan responden laki-laki. Rerata indeks DMF-T responden kelompok usia 16-20 tahun lebih tinggi dibandingkan kelompok usia lainnya (Tabel 3).

Hasil pemeriksaan status karies berdasarkan lama menyirih, frekuensi menyirih, dan jumlah pinang yang dikonsumsi sehari, dijabarkan dalam Tabel 4-6. Berdasarkan Tabel 4, rerata indeks DMF-T pada kelompok dengan lama menyirih 1-5 tahun lebih tinggi dibandingkan kelompok lama menyirih lainnya.

Berdasarkan Tabel 5, rerata indeks DMF-T pada kelompok dengan frekuensi menyirih sehari 6-10 kali lebih tinggi dibandingkan dengan kelompok frekuensi menyirih lainnya. Berdasarkan Tabel 6, rerata indeks DMF-T pada kelompok dengan jumlah pinang yang dikonsumsi per hari $>10$ buah lebih tinggi dibandingkan kelompok lainnya.

Tabel 1. Distribusi hasil pemeriksaan berdasarkan karakteristik responden

\begin{tabular}{llcl}
\hline Karakteristik & & n & $(\boldsymbol{\%})$ \\
\hline \multirow{2}{*}{ Jenis kelamin } & Laki-laki & 34 & 75,6 \\
& Perempuan & 11 & 24,4 \\
\multirow{3}{*}{ Usia } & 16-20 tahun & 17 & 37,8 \\
& 21-25 tahun & 25 & 55,5 \\
& 26-30 tahun & 3 & 6,7 \\
\hline
\end{tabular}

Tabel 2. Distribusi hasil pemeriksaan DMF-T mahasiswa kabupaten Mimika

\begin{tabular}{ccccccc}
\hline \multicolumn{2}{c}{ Hasil pemeriksaan komponen } & Total & Indeks & Rerata & $\begin{array}{c}\text { Kategori } \\
\text { penilaian }\end{array}$ \\
D & $\begin{array}{c}\text { DMF-T } \\
\text { M }\end{array}$ & F & n & DMF-T & & Tinggi \\
\hline
\end{tabular}

Tabel 3. Distribusi hasil pemeriksaan DMF-T berdasarkan karakteristik responden

\begin{tabular}{llccc}
\hline Karakteristik & & n & Total DMF-T & $\begin{array}{c}\text { Rerata } \\
\text { indeks DMF-T }\end{array}$ \\
\hline \multirow{2}{*}{ Jenis kelamin } & Laki-laki & 34 & 180 & 5,3 \\
& Perempuan & 11 & 87 & 8 \\
\multirow{2}{*}{ Usia } & 16-20 tahun & 17 & 107 & 6,3 \\
& 21-25 tahun & 25 & 142 & 5,6 \\
& 26-30 tahun & 3 & 18 & 6 \\
\hline
\end{tabular}

Tabel 4. Distribusi hasil pemeriksaan status karies berdasarkan lama menyirih

\begin{tabular}{lcccccc}
\hline Lama menyirih & $\mathbf{n}$ & D & M & F & Total & $\begin{array}{c}\text { Rerata } \\
\text { indeks DMF-T }\end{array}$ \\
\hline$<1$ tahun & 9 & 60 & 8 & 1 & 69 & 6,6 \\
$1-5$ tahun & 7 & 41 & 8 & 0 & 49 & 7 \\
$>5$ tahun & 29 & 121 & 14 & 14 & 149 & 5,1 \\
\hline
\end{tabular}


Uamang, Leman, Ticoalu: Gambaran status karies pada mahasiswa ...

Tabel 5. Distribusi hasil pemeriksaan status karies berdasarkan frekuensi menyirih per hari

\begin{tabular}{lcccccc}
\hline $\begin{array}{l}\text { Frekuensi menyirih } \\
\text { (per hari) }\end{array}$ & $\mathbf{n}$ & \multicolumn{3}{c}{ Komponen DMF-T } & Total & $\begin{array}{c}\text { Rerata } \\
\text { Indeks DMF-T }\end{array}$ \\
\hline 1-5 kali & & D & M & F & & 5,7 \\
6-10 kali & 31 & 143 & 24 & 11 & 178 & 7 \\
>10 kali & 8 & 49 & 5 & 2 & 56 & 5,5 \\
\hline
\end{tabular}

Tabel 6. Distribusi hasil pemeriksaan status karies berdasarkan jumlah pinang yang dikonsumsi per hari

\begin{tabular}{|c|c|c|c|c|c|c|}
\hline \multirow{2}{*}{ Jumlah pinang } & \multirow{2}{*}{$\mathbf{n}$} & \multicolumn{3}{|c|}{ Komponen DMF-T } & \multirow{2}{*}{ Total } & \multirow{2}{*}{$\begin{array}{c}\text { Rerata indeks } \\
\text { DMF-T }\end{array}$} \\
\hline & & $\mathrm{D}$ & $\mathrm{M}$ & $\mathrm{F}$ & & \\
\hline$<5$ buah & 28 & 139 & 25 & 11 & 175 & 6,2 \\
\hline 6-10 buah & 7 & 22 & 1 & 3 & 26 & 3,7 \\
\hline$>10$ buah & 10 & 61 & 4 & 1 & 66 & 6,6 \\
\hline
\end{tabular}

\section{BAHASAN}

Hasil pemeriksaan status karies pada mahasiswa asal Kabupaten Mimika yang mempunyai kebiasaan menyirih menunjukkan rerata indeks DMF-T yaitu 5,9, artinya rata-rata setiap mahasiswa asal Kabupaten Mimika memiliki 5-6 gigi yang mengalami karies, pencabutan akibat karies, dan telah ditumpat karena karies. Berdasarkan kategori penilaian menurut indikator WHO, indeks ini berada pada kategori status karies tinggi. Hasil penelitian ini membuktikan bahwa penyirih juga mempunyai karies. Penelitian ini berbeda dengan penelitian yang dilakukan oleh Dawn $^{4}$ di Papua Nugini dan Hardiani et al. ${ }^{7}$ di Jawa Timur yang menunjukkan bahwa karies gigi tidak banyak mencolok di antara para pengunyah sirih pinang karena kandungan daun sirih yang berperan sebagai antimikroba.

Hasil penilaian status karies berdasarkan jenis kelamin menunjukkan bahwa nilai rerata indeks DMF-T pada mahasiswa berjenis kelamin perempuan lebih tinggi, namun pada penelitian ini kegiatan menyirih lebih banyak dilakukan oleh mahasiswa berjenis kelamin laki-laki $(75,6 \%)$ dengan rerata indeks DMF-T 5,3. Hal ini mungkin dikarenakan mahasiswa asal Kabupaten Mimika yang berkuliah di Manado berjenis kelamin laki-laki lebih banyak dibandingkan dengan perempuan. Berbeda dengan penelitian yang dilakukan di Malaysia oleh Flora et al. ${ }^{8}$ dimana kegiatan menyirih lebih sering dilakukan oleh perempuan dibandingkan dengan lakilaki. Perilaku menyirih telah menjadi bagian dalam kehidupan masyarakat suku Karo khususnya ibu-ibu rumah tangga yang sering berkumpul untuk bertukar pikiran sambil menyirih; hal ini tampak dalam penggunaan sirih dan kegunaannya dalam beberapa hal di antaranya adalah untuk memperkuat gigi geligi dan untuk menenangkan pikiran. ${ }^{9}$ Hal ini hampir sama dengan penelitian yang dilakukan oleh Croucher et al. di Inggris, dimana salah satu alasan untuk menyirih ialah untuk memperkuat gigi geligi. ${ }^{10}$

Berdasarkan kelompok usia, diperoleh hasil bahwa subyek penelitian yang berusia 21-25 tahun lebih banyak menyirih $(55,6 \%)$ dengan rerata indeks DMF-T 5,6. Hal ini dikarenakan semua subyek penelitian ini ialah mahasiswa yang sementara menempuh studi di Manado. Hasil penelitian ini sejalan dengan penelitian yang dilakukan oleh Wowor et al. ${ }^{11}$ di Manado dengan usia subyek penelitian paling rendah 17 tahun dan paling tinggi 28 tahun, yang disebabkan karena semuanya merupakan mahasiswa yang masih tergolong dalam kelompok usia remaja hingga dewasa awal.

Berdasarkan lama menyirih, pada penelitian ini diperoleh hasil bahwa kelompok subyek penelitian yang lebih banyak ialah menyirih $>5$ tahun $(64,4 \%)$ dengan rerata indeks DMF-T 5,1 (kategori tinggi). Hasil ini berbeda dengan penelitian 
yang dilakukan Samura ${ }^{12}$ di Desa Sibirubiru dimana kebiasaan menyirih dilakukan 1-5 tahun (82,6\%); hal ini mungkin disebabkan karena subyek penelitian ialah remaja dan kebiasaan menyirih telah dilakukan sejak kecil. Hasil penelitian ini selaras dengan penelitian yang dilakukan oleh Wowor et al. ${ }^{11}$ di Manado pada mahasiswa Papua dimana kebiasaan menyirih telah dilakukan 6-10 tahun (50\%).

Penilaian status karies berdasarkan frekuensi menyirih mendapatkan bahwa mayoritas subyek dengan frekuensi menyirih $1-5$ kali sehari $(68,9 \%)$ mendapatkan rerata indeks DMF-T 5,7 (kategori tinggi). Salah satu faktor yang memengaruhi frekuensi menyirih pada penelitian ini ialah kurangnya pinang, sirih, dan kapur di Manado.

Berdasarkan jumlah pinang yang dikonsumsi per hari, pada penelitian ini didapatkan lebih banyak subyek yang menyirih dengan jumlah pinang $<5$ buah perhari $(62,2 \%)$ dengan rerata indeks DMF-T 6,2 (kategori tinggi). Hal ini dikarenakan kebiasaan menyirih hanya dilakukan jika buah pinang, sirih, dan kapur tersedia. Di Kota Manado sendiri, bahan campuran menyirih sulit diperoleh, sehingga bahan campuran untuk menyirih tidak terlalu bervariasi. Kondisi ini berbeda halnya dengan di Papua, dimana bahan campuran menyirih lebih mudah untuk didapatkan. $^{11}$

Pada penelitian ini ditemukan hampir seluruh mahasiswa asal Kabupaten Mimika yang mempunyai kebiasaan menyirih di Manado memiliki karies gigi, dengan rerata indeks DMF-T 5,9 yang termasuk dalam kategori status karies tinggi. Terdapat beberapa faktor yang memengaruhi status karies gigi yang tinggi dalam penelitian ini yaitu sulitnya mendapatkan bahan campuran untuk menyirih yaitu pinang, sirih, dan kapur di Manado, frekuensi menyirih yang tidak teratur, dan tidak menjaga kebersihan gigi dan mulut dengan baik.

Pada penelitian ini pemeriksaan DMF$\mathrm{T}$ yang paling banyak ditemukan yaitu komponen D (Decay) atau gigi yang mengalami karies, dibandingkan dengan $\mathrm{M}$ (Missing) dan F (Filling). Karies yang muncul sebagian besar merupakan karies pada permukaan saja dan hanya terdapat pada gigi geraham. Hal ini disebabkan karena efek menyirih seperti stein yang melekat pada permukaan gigi geraham sehingga mempersulit penyirih membersihkan permukaan gigi tersebut dan memudahkan terjadinya pembentukan karies.

\section{SIMPULAN}

Dari hasil penelitian dan bahasan dapat disimpulkan bahwa

1. Status karies berdasarkan lama menyirih termasuk dalam kategori tinggi.

2. Status karies berdasarkan frekuensi menyirih termasuk dalam kategori tinggi.

3. Status karies berdasarkan jumlah pinang $<5$ buah dan $>10$ buah per hari termasuk dalam kategori tinggi sedangkan jumlah pinang 6-10 buah per hari termasuk dalam kategori sedang.

\section{SARAN}

1. Diharapkan para tenaga kesehatan melakukan penyuluhan kepada masyarakat yang memiliki kebiasaan menyirih tentang pengaruh dari kebiasaan menyirih sehingga para penyirih dapat mengatur frekuensi menyirih dan menjaga kebersihan mulut supaya terhindar dari dampak buruk menyirih.

2. Diperlukan penelitian lebih lanjut dengan menggunakan pemeriksaan kebersihan rongga mulut sehingga status karies pada penyirih dapat dibandingkan secara pasti akibat menyirih.

\section{DAFTAR PUSTAKA}

1. Bakar A. Kedokteran Gigi Klinis (2nd ed). Yogyakarta: Quantum Sinergis Media, 2012; p. 51- 4.

2. Peterson PE. WHO global oral data bank and WHO oral health country/area profile programme, 2000. 
3. Riset Kesehatan Dasar. Laporan kesehatan gigi dan mulut, 2013.

4. Dawn RF. Betel chewing in South East Asia. Lyon, France; 1995.p.51-56.

5. Departemen Pendidikan dan Kebudayaan. Budaya menginang di daerah Papua, Maluku, dan Sulawesi. Jakarta, 2006.

6. Hurlbutt M, Novy B, Young D. Dental caries: A $\mathrm{pH}$ mediated disease. CDHA Journal. 2010;25:9-12.

7. Hardiani DA, Fransiskus WP, Irma YA. Efek aplikasi topikal laktoferin dan piper betel Linn pada mukosa mulut terhadap perkembangan karies. Majalah Ilmiah Kedokteran Gigi Universitas Trisakti. 2007;22:1-4.

8. Flora MS, Mascie-Taylor CGN, Rahman M. Betel quid chewing and its risk factors in Bangladeshi adults. WHO South-East Asia Journal of Public Health. 2012;1(2):169-81.

9. Hasibuan S, Permana G, Aliyah S. Lesi- lesi mukosa mulut yang dihubungkan dengan kebiasaan menyirih di kalangan penduduk Tanah Karo, Sumatera Utara. Dentika Dental Journal 2003;8(2):67-74.

10. Walsh PM, Epstein JB. The oral effects of smokeless tobacco. Journal de I' Association Dentaire Canadienne. 2000;6(1):22-5.

11. Wowor VNS, Supit A, Marbun DR. Gambaran kebiasaan menyirih dan lesi mukosa mulut pada mahasiswa Papua di Manado. e-Journal Universitas Sam Ratulangi; 2013. Available from: ejournal.unsrat.ac.id.

12. Samura JA. Pengaruh budaya makan sirih terhadap status kesehatan periodontal pada masyarakat suku Karo di Desa Sibiru-biru Kabupaten Deli Serdang [Tesis]. Medan: Fakultas Kesehatan Masyarakat Universitas Sumatera Utara; 2009. 